\title{
HUBUNGAN KEJADIAN KANKER SERVIKS DENGAN JUMLAH PARITAS DI RSUD DR. MOEWARDI TAHUN 2013
}

\author{
Hidayat, E. ${ }^{1}$, Hasibuan, D.H.S ${ }^{2}$, Fitriyati, $\mathrm{Y}^{3}$ \\ ${ }^{1}$ Mahasiswa Pendidikan Dokter Fakultas Kedokteran Universitas Islam Indonesia \\ ${ }^{2,3}$ Departemen Obstetri dan Ginekologi Fakultas Kedokteran Universitas Islam Indonesia
}

\begin{abstract}
ABSTRAK
Latar Belakang

Kanker serviks merupakan merupakan salah satu kanker yang paling sering menyerang wanita di seluruh dunia. Berdasarkan data World Health Organization (WHO), lebih dari 250.000 wanita meninggal akibat kanker serviks pada tahun 2005, dan yang terbanyak terjadi di negara berkembang. Di Indonesia terdapat 100-900 kasus kanker leher rahim per 100.000 penduduk. Salah satu faktor risiko yang memiliki hubungan dengan kanker serviks adalah jumlah paritas
\end{abstract}

\section{Tujuan}

Untuk mengetahui hubungan antara kejadian kanker serviks dengan jumlah paritas di RSUD Dr. Moewardi periode Januari 2013 - Desember 2013.

\section{Metode}

Penelitian ini merupakan penelitian analitik komparatif kategorik dengan metode pendekatan case control. Data diambil dari rekam medis pasien dengan menggunakan tehnik consecutive sampling. Kelompok kasus yaitu pasien yang terdiagnosis kanker serviks dan kelompok kontrol adalah pasien yang datang ke RSUD DR. Moewardi untuk antenatal care $(A N C)$.

\section{Hasil}

Dari hasil penelitian didapatkan sebanyak 41 pasien kanker serviks dan 41 pasien tidak dengan kanker serviks. Uji hipotesis dengan Chi-square didapatkan hasil bahwa jumlah paritas $(\mathrm{OR}=16,033 ; 95 \%$ CI 4,773 - 53,855), berpengaruh terhadap kejadian kanker serviks. Dari hasil diatas, dapat disimpulkan bahwa terdapat hubungan antara kejadian kanker serviks dengan jumlah paritas $>3$.

\section{Kesimpulan}

Jumlah paritas memiliki hubungan dengan terjadinya kanker serviks.

Kata Kunci : kanker serviks, jumlah paritas, case control 


\section{ABSTRACT}

\section{Background}

Cervical cancer is one of the most frequent women-attacking cancer in the world. According to the data from World Health Organization (WHO), more than 250.000 women died of cervical cancer in 2005, and most of them occured in developing countries. In Indonesia, there are 100-900 cases of cervical cancer per 100.000 people. One of the risk factors related to cervical cancer is parity.

\section{Objective}

To determine the relationship between cervical cancer and the parity number in DR. Moewardi General Hospital, period of January 2013 - December 2013

\section{Methods}

This was the categoric comparative analytical research with case control approach. Data was taken with consecutive sampling technique from patients' medical record. The case was the patients diagnosed with cervical cancer and the control group was antenatal care (ANC).

\section{Results}

The data analysis from 82 samples consisting of 41 from cases group and 41 from controls with Chi-square test shown that the parity number $(O R=16,033 ; 95 \%$ CI 4,773-53,855) contribute to the incidence of cervical cancer. From the results above, it is concluded that there is a relationship between incidence of cervical cancer and the parity number of $>3$.

\section{Conclusion}

Parity number was correlated with cervical cancer.

Keywords : cervical cancer, parity number, case control

\section{PENDAHULUAN}

Kanker serviks merupakan mayoritas penderita yang datang berobat merupakan salah satu kanker yang paling sudah dalam kondisi kritis dan penyakitnya sering menyerang wanita di seluruh dunia. sudah dalam stadium lanjut ${ }^{2}$.

Menurut, World Health Organization (WHO), kanker jenis ini menempati urutan kedua sebagai kanker yang sering menyerang wanita dan yang terbanyak terjadi di negara berkembang ${ }^{1}$. Tingginya kasus di negara berkembang ini disebabkan oleh terbatasnya akses skrining dan pengobatan sehingga
Infeksi Human papilloma virus (HPV) telah terbukti seara biologi dan epidemiologi dalam menyebabkan kanker serviks. Sebanyak $70 \%$ dari kanker serviks disebabkan jenis HPV-16 dan HPV-18. Meskipun HPV merupakan penyebab penting, namun kofaktor lain juga diperlukan 
untuk timbulnya kanker ini, seperti penggunaan jangka panjang kontrasepsi hormonal, paritas tinggi, merokok, imunosupresi, kekurangan makanan tertentu, genetik dan faktor virus. ${ }^{3,4}$

Banyaknya anak yang dilahirkan berpengaruh dalam timbulnya penyakit kanker serviks. Paritas merupakan salah satu faktor risiko terjadinnya kanker serviks dengan besar risiko 4,55 kali untuk terkena kanker serviks pada wanita dengan paritas >3 dibandingkan wanita dengan paritas 3 . Hal tersebut berhubungan dengan terjadinya eversi epitel kolumner serviks selama kehamilan yang menyebabkan dinamika baru epitel metaplastik imatur yang dapat meningkatkan risiko transformasi sel serta trauma pada serviks sehingga memudahkan terjadi infeksi HPV. ${ }^{5}$

Jika diabaikan, kanker serviks yang invasif hampir selalu berakibat fatal, apalagi jika diketahui dalam kondisi stadium lanjut ${ }^{1}$.

\section{METODE PENELITIAN}

Penelitian ini merupakan penelitian untuk mengetahui apakah terdapat hubungan antara kejadian kanker serviks dengan jumlah paritas. Rancangan penelitian ini adalah penelitian analitik komparatif kategorik dengan pendekatan case control, menggunakan data sekunder dari rekam medis di Rumah Sakit Umum Daerah Dr. Moewardi tahun 2013.
Populasi yang digunakan pada penelitian ini adalah pasien yang didiagnosis dengan kanker serviks di RSUD Dr. Moewardi. Sampel pada penelitian ini mempunyai kriteria yang telah ditentukan, yaitu kriteria inklusi adalah pasien yang terdiagnosis kanker serviks pada semua stadium dan tercantum jumlah paritas pada rekam medis pasien. Sedangkan kriteria eksklusi adalah pasien terdapat riwayat penggunaan kontrasepsi hormonal $>4$ tahun.

Cara pengambilan sampel dalam penelitian ini menggunakan teknik consecutive sampling yaitu dengan cara mengambil sampel yang sudah ada dan pemilihan sampel yang memenuhi kriteria yang sudah ditentukan. Jumlah pengambilan sampel yang memenuhi kriteria akan diambil sesuai dengan besaran sampel yang telah ditentukan, yaitu 82 sampel. Dengan tujuan untuk mendapatkan data dengan jumlah yang cukup representatif untuk dianalisis dan menggambarkan kondisi populasi penelitian.

Analisis univariat pada penelitian ini menggambarkan distribusi dan frekuensi pasien yang terdiagnosis kanker serviks dan tanpa diagnosis kanker serviks yang tercantum jumlah paritas. Kemudian di gambarkan juga mengenai distribusi dan frekuensi pasien berdasarkan jumlah paritas, umur, outcome, tindakan terapi serta stadium klinis yang diterima pasien tersebut.

Selanjutnya, dilakukan analisis dengan menggunakan uji statistik Chi- 
Square, dimana batas kemaknaan statistik ( $p$ value) yang dipakai adalah sebesar 0,05 untuk mengetahui adanya hubungan antara variabel bebas dengan variabel tergantung. Jika didapatkan p-value $\leq 0.05$ maka hitungan statistik bermakna, sebaliknya jika $p$-value >0.05 maka hasilnya tidak bermakna. Untuk mengetahui faktor resiko antara kedua variabel dengan uji statistik di gunakan odd ratio (OR) dengan tabel $2 \times 2 .{ }^{6}$

\section{HASIL PENELITIAN}

Penelitian ini berlangsung selama 1 bulan pada bulan Februari 2014 di Rumah Sakit Umum Daerah Dr. Moewardi. Data yang diambil dari periode Januari 2013 hingga Desember 2013 . Rumah sakit ini merupakan rumah sakit tipe A yang terletak di kota Surakarta. Selama periode tersebut, jumlah penderita kanker serviks yang dirawat di RSUD Dr Moewardi sebanyak 1113 pasien. Di rumah sakit ini kanker Serviks termasuk ke dalam 10 besar penyakit penyebab kematian.

Data yang diambil berjumlah 82 orang, termasuk kelompok kasus dan kelompok kontrol yang berasal dari Rekam Medis (RM) pasien di Rumah Sakit Umum Daerah Dr. Moewardi. Dari jumlah 82 tersebut, 41 pasien diantaranya merupakan kelompok kasus yang terdiagnosis kanker serviks yang memenuhi kriteria inklusi yang sudah ditetapkan sebelumnya dan 41 sisanya adalah sebagai kelompok kontrol, sehingga
82 jumlah sampel tersebut dapat digunakan sebagai sampel dalam penelitian ini karena sudah memenuhi batasan sampel yang sudah ditentukan dalam besar sampel penelitian.

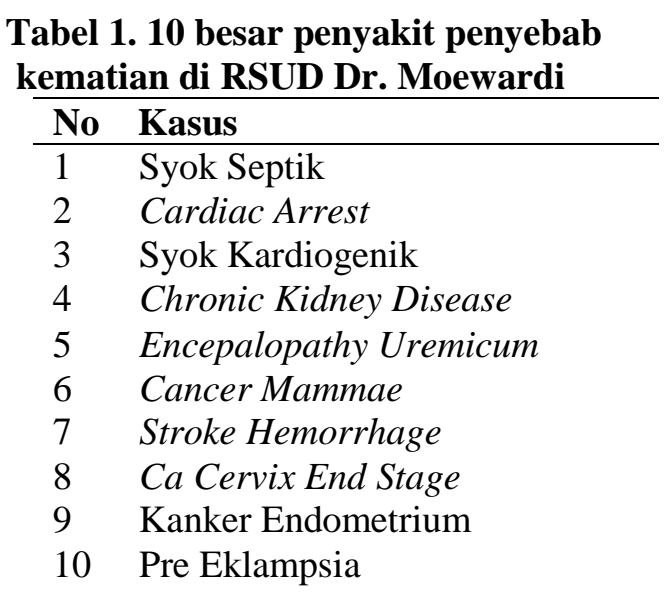

Sedangkan kontrol yang digunakan dalam penelitian ini adalah pasien di RSUD Dr. Moewardi yang tidak terdiagnosis kanker serviks. Diagnosis yang diambil sebagai kontrol adalah antenatal care (ANC). Didapatkan pasien sebanyak 41 orang yang dipilih secara random. Data kemudian diolah dengan analisis univariat dan bivariat.

\section{Karakteristik Sampel Penelitian}

Dari hasil penelitian didapatkan bahwa, sebanyak 41 pasien pada kelompok kasus kanker serviks yang ditemukan, diketahui sebanyak 26 orang $(63,4 \%)$ mempunyai paritas >3 dan sebanyak 15 orang $(36,6 \%)$ mempunyai paritas $\leq 3$. Sedangkan sebanyak 41 pasien pada kelompok kontrol yang tidak kanker serviks, diketahui sebanyak 4 orang $(9,8 \%)$ mempunyai paritas >3 dan sebanyak 37 orang $(90,2 \%)$ mempunyai paritas $\leq 3$. Hal 
ini dapat diartikan bahwa pasien yang mengalami kanker serviks pada kelompok kasus paling banyak terjadi pada paritas $>3$, yaitu sebanyak 26 orang $(63,4 \%)$. Dari semua total sampel yang diambil yaitu 82 orang. Distribusi jumlah paritas pada kelompok kasus kanker serviks dan kelompok kontrol yang tidak kanker serviks dapat dilihat pada tabel 4 .

Usia pasien dibagi menjadi 2 kategori, yaitu usia $<50$ tahun dan usia $\geq 50$ tahun. Usia dengan risiko tinggi kanker serviks adalah pasien yang berusia $>50$ tahun. Dari hasil penelitian didapatkan bahwa, sebanyak 41 pasien pada kelompok kasus kanker serviks yang ditemukan, diketahui sebanyak 16 orang $(39,1 \%)$ yang berusia $<50$ tahun dan sebanyak 25 orang $(60,9 \%)$ yang berusia $\geq 50$ tahun. Sedangkan sebanyak 41 pasien pada kelompok kontrol yang tidak kanker serviks, diketahui sebanyak 40 orang $(97,6 \%)$ yang berusia $<50$ tahun dan sebanyak 1 orang $(2,4 \%)$ yang berusia $\geq 50$ tahun. Dari semua total sampel yang diambil yaitu 82 orang. Umur penderita kanker serviks termuda adalah usia 33 tahun, sedangkan usia tertua penderita kanker serviks adalah usia 79 tahun. Distribusi usia pasien pada kelompok kasus kanker serviks dan kelompok kontrol yang tidak kanker serviks dapat dilihat pada tabel 2.

Berdasarkan hasil penelitian yang dilakukan, didapatkan data bahwa karakteristik outcome pada pasien kanker serviks dibagi menjadi 4 kategori yaitu: pulang atas permintaan sendiri sebanyak 2 orang $(4,9 \%)$, membaik sebanyak 32 orang (78\%), meninggal <48 jam sebanyak 3 orang $(7,3 \%)$ dan meninggal $>48$ jam sebanyak 4 orang $(9,8 \%)$. Dilihat dari data tersebut terlihat outcome dari kanker serviks sebanyak 7 orang $(17,1 \%)$ yang meninggal. Diantaranya yang meninggal $<48$ jam berada pada stadium IIIB,

Sedangkan yang meninggal $>48$ jam berada pada stadium IB2 dan IIIB.

Tabel 2. Distribusi pasien berdasarkan usia pasien

\begin{tabular}{lccc}
\hline \multicolumn{1}{c}{ Usia } & $\begin{array}{c}\text { Kelompok kasus } \\
\text { (kanker serviks) }\end{array}$ & $\begin{array}{c}\text { Kelompok kontrol } \\
\text { (tidak kanker serviks) }\end{array}$ & Jumlah \\
\hline$<50$ tahun & $16(39,1 \%)$ & $40(97,6 \%)$ & $56(68,3 \%)$ \\
$\geq 50$ tahun & $25(60,9 \%)$ & $1(2,4 \%)$ & $26(31,7 \%)$ \\
\hline Jumlah & $41(100 \%)$ & $41(100 \%)$ & $82(100 \%)$ \\
\hline
\end{tabular}


Pengobatan yang paling banyak

Untuk karakteristik stadium klinis didapatkan oleh kelompok kasus kanker pada pasien kanker serviks yang didapatkan serviks adalah kemoterapi sebanyak 19 pada kelompok kasus adalah terbanyak pada

Tabel 3. Karakteristik Dasar dari Kelompok Kasus yang Diambil

\begin{tabular}{|c|c|c|}
\hline Variabel & Kanker Serviks & Presentase \\
\hline $\begin{array}{l}\text { Outcome } \\
\text { - Membaik } \\
\text { - } \text { Pulang atas permintaan sendiri } \\
\text { - Meninggal }<48 \text { jam } \\
\text { - Meninggal }>48 \text { jam }\end{array}$ & $\begin{array}{c}32 \\
2 \\
3 \\
4\end{array}$ & $\begin{array}{l}78 \% \\
4,9 \% \\
7,3 \% \\
9,8 \%\end{array}$ \\
\hline $\begin{array}{l}\text { Tindakan Terapi } \\
\text { - } \text { Operasi histerektomi radikal, } \\
\text { Kemoterapi } \\
\text { - } \text { Kemoterapi, Radioterapi } \\
\text { - Kemoterapi }\end{array}$ & $\begin{array}{l}17 \\
5 \\
19\end{array}$ & $\begin{array}{l}41,5 \% \\
12,2 \% \\
46,3 \% \\
\end{array}$ \\
\hline $\begin{aligned} & \text { Stadium } \\
&- \text { IB2 } \\
&- \text { IIA } \\
&- \text { IIB } \\
& \text { - } \text { IIIB }\end{aligned}$ & $\begin{array}{c}4 \\
11 \\
6 \\
20\end{array}$ & $\begin{array}{c}9,6 \% \\
26,9 \% \\
14,7 \% \\
48,8 \%\end{array}$ \\
\hline
\end{tabular}

orang (46,3\%), pengobatan dengan stadium IIIB sebanyak 20 orang $(48,8 \%)$, kombinasi antara kemoterapi dan operasi stadium IIA sebanyak 11 orang (26,9\%), histerektomi radikal sebanyak 17 orang stadium IIB 6 sebanyak 6 orang $(14,7 \%)$ dan $(41,5 \%)$ dan terapi kombinasi antara stadium IB2 sebanyak 4 orang $(9,6 \%)$. Hal kemoterapi dan radioterapi sebanyak 5 orang ini dapat diartikan bahwa pasien yang $(12,2 \%)$. Hal ini dapat diartikan bahwa mengalami kanker serviks pada kelompok pasien yang mengalami kanker serviks pada kasus paling banyak pada stadium IIIB, kelompok kasus paling banyak mendapatkan yaitu sebanyak 20 orang $(48,8 \%)$. pengobatan kemoterapi, yaitu sebanyak 19 orang $(46,3 \%)$.

\section{Hubungan Kejadian Kanker Serviks dengan Jumlah Paritas}

Berdasarkan hasil uji statistik dengan menggunakan Chi-square, didapatkan $p$ value $0,000(\mathrm{p}<0,05)$ yang berarti terdapat hubungan yang signifikan pada wanita yang jumlah paritas >3 dengan kejadian kanker serviks. Didapatkan odd ratio (OR) sebesar 16,03 dan confidence interval (CI 95\%) sebesar 4,77-53,85. Rentang confidence interval (CI 95\%) cukup lebar disebabkan oleh power penelitian kurang besar, tingkat kesalahan 5\%, dan jumlah sampel yang kurang besar sehingga didapatkan nilai 
confidence interval (CI 95\%) cukup lebar. Berarti pada orang yang memiliki jumlah paritas >3 lebih berisiko 16,03 kali terkena kanker serviks dibandingkan orang yang memiliki jumlah paritas $\leq 3$. Interpretasi dari hasil uji Chi-square test pada penelitian dapat di lihat bawah ini.

\section{PEMBAHASAN}

Di Indonesia terdapat 100-900 kasus kanker leher rahim per 100.000 penduduk. Penyebab kanker serviks 99,7\% disebabkan oleh Human Papiloma Virus (HPV) Onkogenik. HPV tipe 16 dan tipe 18 merupakan penyebab utama pada $70 \%$ kasus kanker serviks di dunia. Setiap perempuan tanpa memandang usia dan latar belakang berisiko terkena kanker leher rahim. Tingginya kasus di negara berkembang ini disebabkan oleh terbatasnya akses skrining dan pengobatan sehingga mayoritas penderita yang datang berobat sudah dalam kondisi kritis dan penyakitnya sudah dalam stadium lanjut $^{2}$. Hal ini terjadi di RSUD Dr. Moewardi pada tahun 2013 bahwa 48,8\% datang sudah berada pada stadium III. Hal ini mempengaruhi outcome, sehingga sebanyak 7 orang dari 41 pasien $(17,1 \%)$ meninggal. Angka 5 year relative survival rate hanya $12,1 \%$ untuk kanker serviks. ${ }^{7}$

Pasien kanker serviks pada penelitian ini lebih banyak pada usia lebih dari 50 tahun, sementara insidensi tertinggi pasien yang terdiagnosis kanker servik di Amerika adalah pada rentang usia 40 sampai 49 tahun dengan OR 14.2 (CI 95\% $14.0-14.4$ ). Semakin muda dan semakin tua semakin tidak berisiko terkena kanker serviks. ${ }^{8}$

Pada penelitian ini juga didapatkan data dari asal daerah pasien kanker serviks. Didapatkan paling banyak adalah dari daerah Sragen sebanyak 8 orang. Hal ini dikarenakan banyak rumah sakit di daerah sragen yang belum lengkap fasilitas kesehatan sehingga memungkinkan banyak warga sragen datang berobat ke rumah sakit dr. Moewardi karena RSUD Dr. Moewardi merupakan rumah sakit rujukan yang sudah lengkap fasilitas kesehatan dan yang paling dekat dengan daerah sragen. Sedangkan yang paling sedikit ada di daerah Ngawi, Blora, Tawangharjo, Salatiga, DKI Jakarta dan Jambi yang masing-masing sebanyak 1 orang.

Pada penelitian ini didapatkan hasil bahwa orang yang memiliki jumlah paritas >3 lebih banyak terkena kanker serviks yaitu 26 orang $(63,4 \%)$ atau berisiko 16,03 kali terkena kanker serviks daripada orang yang memiliki jumlah paritas $\leq 3$. Hasil penelitian ini sejalan dengan penelitian yang telah dilakukan oleh Setyarini (2009) ${ }^{5}$, bahwa paritas >3 meningkatkan risiko kanker serviks sebesar 5,5 kali lebih besar daripada paritas $\leq 3$. Perempuan dengan paritas tinggi terkait dengan terjadinya eversi epitel kolumner serviks selama kehamilan yang menyebabkan dinamika baru epitel 
metaplastik imatur yang dapat meningkatkan risiko transformasi sel serta trauma pada serviks sehingga memudahkan untuk terjadi infeksi HPV ${ }^{9}$

Suatu studi case control di Turki menunjukkan paritas $>3$ meningkatkan risiko kanker serviks sebesar $9.127 \quad(p=0.002) .{ }^{10}$ Paritas meningkatkan risiko kanker serviks pada wanita dengan infeksi persistent HPV (HR 1.78, 95\% CI:1.07-2.94). ${ }^{11}$

Semakin sering melahirkan, semakin besar risiko mendapatkan kanker serviks. Paritas dapat meningkatkan insiden kanker serviks, lebih banyak merupakan refleksi dari aktivitas seksual dan saat mulai kontak seksual pertama kali daripada akibat trauma persalinan. Pada wanita dengan paritas 5 atau lebih mempunyai risiko terjadinya kanker serviks 2,5 kali lebih besar dibanding dengan perempuan dengan paritas 3 atau kurang. ${ }^{12}$

Hal ini dibuktikan juga pada suatu studi kohort dimana didapatkan bahwa infeksi HPV lebih mudah ditemukan pada wanita hamil dibandingkan yang tidak hamil. Selain itu, pada kehamilan terjadi penurunan kekebalan seluler. ${ }^{13}$

Wanita yang mempunyai paritas tinggi sebaiknya melakukan skrining dengan pemeriksaan pap smear karena karena dapat menurunkan kejadian kanker serviks terutama pada usia tua. ${ }^{14}$

Pada penelitian ini memiliki banyak keterbatasan, diantaranya adalah data yang digunakan adalah data rekam medis atau data sekunder, sehingga kemungkinan terdapat kesalahan dalam pencatatan yang dilakukan oleh petugas atau data yang ada kurang lengkap sehingga peneliti tidak bisa mendeskripsikan secara rinci. Pada penelitian ini tidak diteliti pengaruh dari faktor risiko yang lain pada kanker serviks, sehingga masih bisa dimungkinkan adanya pengaruh dari faktor risiko yang lain (contoh: lingkungan dan makanan) yang ikut berpengaruh.

\section{KESIMPULAN}

Terdapat hubungan yang signifikan pada wanita yang jumlah paritas >3 dengan kejadian kanker serviks.

\section{SARAN}

Perlu dilakukan penelitian lebih lanjut mengenai faktor risiko lain yang mempengaruhi terjadinya kanker serviks.

\section{DAFTAR PUSTAKA}

1. Kementerian Kesehatan Republik Indonesia. Vaksin HPV untuk Perangi Kanker Serviks 2013.

http://www.depkes.go.id/index.php/berita/pre ss-release/873-vaksin-hpv-untuk-perangikanker-serviks.html. Diakses pada tanggal 8 September 2013

2. Nurwijaya H, Andrijono, Suheimi HK Kanker Serviks. Elex Media Komputindo, Jakarta. 2010.

3. Mu noz N, Castellsagu'e X, de Gonz'alez $\mathrm{AB}$, Gissmann L. Chapter 1: HPV in the etiology of human cancer Vaccine 24S3 2006 S3/1-S3/10.

4. Jones EE, Wells SI. Cervical cancer and human papillomaviruses: inactivation of retidattnoblastoma and other tumor 
suppressor pathways. Curr Mol Med 6:795, 2006.

5. Setyarini E. Faktor-Faktor Yang Berhubungan Dengan Kejadian Kanker Leher Rahim di RSUD Dr Moewardi Surakarta, Skripsi, Jurusan Kesehatan Masyarakat Fakultas Ilmu Kesehatan, Universitas Muhamadyah Surakarta. 2009

6. Dahlan MS. Langkah-Langkah Membuat Proposal Penelitian Bidang Kedokteran dan Kesehatan. Sagung Seto, Jakarta. 2008.

7. Desen W. Buku Ajar Onkologi Klinis Edisi 2. Balai penerbit FKUI: Jakarta. 2008

8. Posadas EM, Kotz HL. Bethesda Handbook of Clinical Oncology, 2nd Edition. Medical Oncology Clinical Research Unit, National Cancer Institute, National Institutes of Health, Bethesda, Maryland, Lippincott Williams \& Wilkins. 2005.

9. Center for disease control and prevention. Human Papillomavirus-Associated CancerUnited States. 2004-2008. MMWR Morb Mortal Wkly Rep 2012 61(15);258-261.

10. Reis N, Beji NK, Kilic D. Risk Factors for Cervical Cancer: Results from a HospitalBased Case-Control Study. International Journal of Hematology and Oncology UHOD. 2011 3(21).
11. Jensen KE, Schmiedel S, Norrild B, Frederiksen K, Iftner T, Kjaer SK. Parity as a cofactor for high-grade cervical disease among women with persistent human papillomavirus infection: a 13-year followup. British Journal of Cancer 2013 108, 234239.

12. Fatimah AN, Studi Kualitatif Tentang Perilaku Keterlambatan Pasien Dalam Melakukan Pemeriksaan Ulang Pap Smear di Klinik Keluarga Yayasan Kusuma Buana Tanjung Priuk Jakarta Tahun 2008, Skripsi, Jurusan Kesehatan Masyarakat Fakultas Ilmu Kesehatan, Universitas Indonesia. 2009.

13. Sawaya GF, McConnell KJ, Kulasingam SL. Risk of Cervical Cancer Associated With Extending the Interval Between CervicalCancer Screenings. N Engl Med J 2003, 67 349-416.

14. Sasieni P, Castanon A, Cuzick J, Snow J. Effectiveness of cervical screening with age: population based case-control study of prospectively recorded data 